\title{
Federalism at the Crossroads: Crisis of the Linguistic Minorities in India
}

\author{
Pritin Dutta \\ Assistant Professor in Political Science, Government General Degree College, Tehatta. \\ Nadia, West Bengal, India. ORCID: 0ooo-0oo2-8834-1904. \\ Email id:duttapritinı@gmail.com
}

\begin{abstract}
Polyglot federations face a challenge in reconciling between the national identities and regional identities. Demand for a second States Reorganisation Commission (SRC) in India in 2015 by some groups bears testimony to this fact. On the question of political remapping in post-independence period, the constitutional ancestors sought to save India from another religious bigotry and the menace of casteism. The emergence of language as a viable alternative gained momentum in Nagpur session (1920) of the Indian National Congress (INC). But subsequent years encountered with a difficulty in adopting territorial solution for accommodating India's multilingual identities. Pre-constitutional, extra-constitutional and constitutional arrangements have faced the challenge of linguistic accommodation. Dar Commission warned the risk of federal remapping with existing linguistic pocket corridors in the states. Inter-state migration has proliferated the problem over the years. Even the SRC could not provide adequate safeguards for large number of linguistic minorities living in all states (Kerala becomes exception with 97.03\% linguistic majorities). There new minority emerged and accommodated but with limits. Census report of 2011 shows India having 19,569 languages which stood 1369 after linguistic scrutiny. Territorial machinations appear inadequate to satisfy all linguistic groups but only to incur huge expenditure. Indian federalism seems deficient in non-territorial power sharing which has succeeded in countries like Belgium in the form of Consociational representation. With its promise of inclusivity by means of a possible alternative it demands the attention of the policy makers as well as the academia.
\end{abstract}

Keywords: Polyglot federations, political remapping, States Reorganisation Commission, linguistic minorities, Consociational Representation

\section{Introduction}

India with her vast multi-ethnic diversities has been commendably successful in maintaining a federation, as compared to the developed federal systems of the first world. Somewhat surprisingly, federal paradigm has been reduced to a half-cultivated discipline among the pupils of constitutional and political studies in India where federalism is meant to be a politicoadministrative mechanism in a large region. Administrative decentralization may be possible without having a federated system, but remains hostile where demography of the region is enriched with vibrant diversity. This diversity lies with one's identity ranging from caste, religion, region, culture to language. India like any other multi-ethnic and polyglot federation seeks to accommodate her diverse identities with her national identity. After the fatal consequences of religion and caste, language appeared to be an obvious choice in the process of such accommodation which remains to be a challenge for any federal governance.

(c) AesthetixMS 2020. This Open Access article is published under a Creative Commons Attribution Non-Commercial 4.o International License (http://creativecommons.org/licenses/by-nc/4.o/), which permits non-commercial re-use, distribution, and reproduction in any medium, provided the original work is properly cited. For citation use the DOI. For commercial re-use, please contact editor@rupkatha.com. 
Most notable experts on federal studies like Professor Daniel Elazar, Professor Ronald Watts have agreed to the indispensability of federal governance required for administrative convenience in polyglot countries. While Elazar put forwarded the concepts of 'shared rule' and 'regional selfrule,' Watts had provided six universally recognized attributes of federations which are namely 1. Two kinds of government having independent access to citizens. 2. Formal and clear distribution of executive, legislative and financial powers between the governments. 3. Existence of a second chamber in the legislature giving way for the representation of regional views. 4. Giving way to regional governments in the amendment of the constitution by seeking their consent on concerned occasions. 5. Existence of a strong third agency (Judiciary in case of India) which he aptly calls 'umpire.' The umpire is supposed to work independently and resolve issues over the question of constitutional deadlock between the governments. 6. Making inroads for processes and institutions in cases of overlapping of authority rights between the kinds of governments (Watts, 2007).

Apart from these theoretical insights, the popular discourse on Indian constitution hails territorialism as an essential feature of Indian federation. Right from theory to practice, territorialism has exposed India's federal handicap over the years with the emerging demands for new states on linguistic lines even after so many decades of the SRC came into effect. Demand for a second SRC by groups like All Bodo Students' Union (ABSU), Kuki State Demand Committee (KSDC) and Indigenous People's Front of Tripura (IPFT) in 2015 has reinforced the agenda of new states formation (The Economic Times, 2015) India's federation remains complimentary to the process of state's reorganization. Since reorganization took place mostly on linguistic lines, such reorganized states gave birth to new linguistic minorities following the post-independence initiatives like the Linguistic Provinces Commission (Dar Commission), Linguistic Provinces Committee (JVP Committee) and the SRC where linguistic reorganization was conceded in the name of popular wish, without having any explicit surrender to it. This was perhaps the INC realized the difficulty of linguistic determinism following the design of dispersion of large number of linguistic groups in almost all the states except Kerala. Dar commission indicated the risk of linguistic statehood along with existing linguistic pocket corridors and said only geographical contiguity could help such reorganization. Inter-state migration over the years has increased the number of linguistic minorities in almost all the states. Evident with the census report 2011, broadly 1369 linguistic groups exist in India. In its conclusive remark the Commission categorically stated,

"Linguistic homogeneity in the formation of new provinces is certainly attainable within certain limits but only at the cost of creating a fresh minority problem. More than half the Malayalam and Kannada speaking people are living in Indian States, and only a little less than half of the Telugu and Marathi speaking people are living either in Indian States or in Union Provinces from which they cannot be transferred to new linguistic provinces either for want of geographical Contiguity or want of their consent to be so transferred" (Linguistic Provinces Commission, 1948: 28).

Right at this situation, how far is it feasible to stick to linguistic determinism in the federal scene, remains a matter of introspection. Should we look for a better alternative beyond territorialism? Should we drive ourselves in the roads of comparative federalism? These issues need to be addressed. 


\section{Methodology}

This paper is the outcome of empirical research where primary data viz. governmental as well as extra-governmental reports, reports of several sessions and election manifestos of the INC have been the key materials apart from books and journals. A combined approach of historical, scientific and comparative method of research has been adopted while preparing the paper.

\section{History Revisited: In Search of Roots}

Well, the history of India's journey of linguistic federalism dates back to the formation of Odisha in the name of reorganization of states. But the $21^{\text {st }}$ session of the INC in Benaras in 1905 following the partition of Bengal, marks the watershed in the political journey of linguistic reorganization. Explicit in the resolution of the session,

"That this Congress recommends the adoption of some arrangement which would be consistent with administrative efficiency, and would place the entire Bengali community under one undivided administration either by the appointment of a Governor and Council or by the adoption of some other administrative arrangement that may be thought desirable" (Indian National Congress, 1905: 62).

Subsequent years witnessed some positive developments in this direction. 1908 was the year when 21 vernacular units of the INC were promoted to Provincial Congress Committees after a rationalization on the basis of linguistic zones. Nagpur session in 1920 was crucial to the extent that it took the pledge of linguistic reorganization of states as a part of the national struggle. The INC reaffirmed this conviction in 1927, Nehru Committee Report in 1928, 1937, 1938 and of course in its election manifesto in 1945 .

INC'c arrival in the helm of power after independence brought it in front of a challenge in the materialization of its linguistic commitment. Though difficult to achieve, yet linguistic reorganization dominated the political scene owing two important factors- 1 . Integration of about 560 princely states with the British Indian territory was believed to be carried out in a hurried and haphazard manner, hence circumstantial and irrational. Rational redrawing became the imperative. 2. With language being the primary source of identity, constitutional ancestors decided to rely upon the linguistic lines to preclude the menace of casteism and religious nationalism.

The difficulty following the vast zigzag design of dispersion of various linguistic groups prompted INC as well as its top leaders like Gandhi and Nehru to roll their earlier decision back. It was not easy to back out from any political commitment. Year 1948 brought India's federal journey to a crossroad where three famous initiatives, namely The Linguistic Provinces Commission or Dar Commission, The Linguistic Provinces Committee or JVP Committee and afterwards States Reorganisation Commission (SRC) in 1953. All these sought to bypass linguistic exclusivity at the cost of administrative convenience, geographical and cultural homogeneity and of course popular wish. In view of Dar Commission,

"The formation of linguistic provinces is sure to give rise to a demand for the separation of other linguistic groups elsewhere. Claims have already been made by Sikhs, Jats and others and these demands will in course of time be intensified and become live issues if once the formation of linguistic provinces is decided upon" (Linguistic Provinces Commission, 1948: 26). 
JVP Committee stood for a temporary halt in linguistic reorganization with national integration as of primary importance. Notwithstanding Dar Commission's report, the committee regarded INC's policy of linguistic reorganization as old and of late, a secondary issue. It observed,

“...the old Congress policy of having linguistic provinces can only be applied after careful thought being given to each separate case, and without creating serious administrative dislocation or mutual conflicts which would jeopardize the political and economic stability of the country" (Linguistic Provinces Committee, 1949: 15).

SRC's proposed safeguards appear inadequate for the linguistic minorities where it had recourse to good sense of the people, judicial access etc. It explained and showed execution of linguistic reorganization could lead to a dual jeopardy- 1. It could invite further demands of separation, 2. Violate the constitution by way of challenging the right to freely move and reside anywhere in the country. Thus it paved the way for the INC to reform its earlier policy. Needless to say, the limitations put forwarded by all these three ad hoc institutions are of crucial significance.

\section{Linguistic Minorities: Identifying the Hiatus}

Linguistic minorities are the result of uneven federal exercises in India, though rightfully be the cause of separation. Apart from the SRC's recommendations, promises made in the election manifesto of the INC in 1945 and 2019 show its standpoint on the linguistic question. In 2019, the INC showed its commitment to save linguistic minorities from all kinds of discrimination conforming to the fundamental rights guaranteed by the constitution (All India Congress Committee, 2019). As a matter of fact, constitutional safeguards are confined to conventional solutions struggling to redress the grievances of linguistic minorities by way of non-territorial management. The census report of 2011 presents a somewhat hostile scenario on the question of linguistic minorities. After several occasions of reorganization on linguistic lines conceding to popular demand, sizeable linguistic minorities present in almost all the states. Evidently, most of the states have almost millions and billions of linguistic minorities (barring Kerala being the highest linguistic homogeneous state with 97.03 percent Malayalam speaking people.) who are still underrepresented in the federal scene. The bifurcation of Bombay into Maharashtra and Gujarat was executed by conceding to linguistic demands. Nevertheless, the existence of huge numbers of linguistic minorities there indicates the limitations of territorial machination of Indian federalism.

Primarily three pivotal observations from the data published in the report of 2011, arrived in the lingo-federal sphere. 1. There are states which have substantial percentage of linguistic minorities with relatively small population, 2 . There are states which have relatively small percentage of linguistic minorities with a huge population leading to their existence in substantial number, 3 . There are states and few union territories which have substantial numbers of non-scheduled linguistic groups, sometimes larger than the scheduled groups (Census of India, 2011). This has added another dimension pivotal to the research of federal studies. Following two figures will be helpful to apprehend the demography of linguistic minorities in India. 
5 | Federalism at the Crossroads: Crisis of the Linguistic Minorities in India

Table 1: State wise data on linguistic minorities in India

State Linguistic minorities in number Linguistic minorities in percentage

\begin{tabular}{|c|c|c|}
\hline Assam & $16,108,318.3312$ & 51.62 \\
\hline Jammu \& Kashmir & $5,860,550.4246$ & 46.73 \\
\hline Manipur & $1,333,655 \cdot 798$ & 46.7 \\
\hline Goa & $49,4,300.9005$ & 33.89 \\
\hline Karnataka & $2,0442,486.3762$ & 33.46 \\
\hline Maharashtra & $349,14,705.2631$ & 31.07 \\
\hline Bihar & $234,01,556.8096$ & 22.48 \\
\hline Odisha & $72,61,539 \cdot 714$ & $17 \cdot 3$ \\
\hline Andhra Pradesh ${ }^{\#}$ & $139,13,537.8165$ & 16.45 \\
\hline Gujarat & $84,79,688.7876$ & 14.03 \\
\hline West Bengal & $1,25,77,848.647$ & 13.78 \\
\hline Tamil Nadu & $83,90,699.589$ & 11.63 \\
\hline Punjab & $2,82,4271.8084$ & 10.18 \\
\hline
\end{tabular}

Source: Census Report of India, 2011.

\# Andhra Pradesh was bifurcated and the state of Telangana came into existence on $2^{\text {nd }}$ June, 2014. Another course of event witnessed the creation of two union territories of Jammu \& Kashmir and Ladakh on $31^{\text {st }}$ October, 2019 bifurcating the state of Jammu \& Kashmir.

Table 2: State/Union Territory wise data on schedule and non-scheduled linguistic groups in India

\begin{tabular}{|c|c|c|}
\hline State/Union Territory & $\begin{array}{l}\text { Scheduled speakers } \\
\text { in percentage }\end{array}$ & $\begin{array}{r}\text { Non-scheduled } \\
\text { in percenta }\end{array}$ \\
\hline Sikkim & 73.64 & 26.36 \\
\hline Arunachal Pradesh & 27.87 & 72.13 \\
\hline Nagaland & 11.87 & 88.13 \\
\hline Manipur & 58.2 & 41.8 \\
\hline Mizoram & 12.35 & 87.65 \\
\hline Tripura & 69.78 & 30.22 \\
\hline Meghalaya & 14.65 & $85 \cdot 35$ \\
\hline Dadra \& Nagar Havelli ${ }^{\#}$ & 62.32 & 37.68 \\
\hline Andaman \& Nicobar Islands ${ }^{\#}$ & 85.24 & 14.76 \\
\hline
\end{tabular}

Source: Census Report of India, 2011.

\# Union Territories

The tables, though not inclusive in character, presents the picture of linguistic minorities as well as non-scheduled linguistic groups in several states and union territories in India. Figure two deserves a special attention to point out the linguistic discriminations and the constitutional irony. The constitution by way of its fundamental rights, especially right to education (Art. 29-30) has allowed limited right to the linguistic minorities by ensuring education in one's own language or any other language one wishes (Pylee, 2008). Even the New Education Policy of India, 2020 which has emphasized on the need for the- 
"promotion of Indian languages is possible, if they are used regularly and if they are used for teaching-learning. It is due to the above reasons that Indian languages must get due attention and care" (Ministry of Human Resource Development, 2020: 51).

But prevention of linguistic discrimination remains unspecified in the provisions of right to equality, particularly article 15 thus enumerates,

"The state shall not discriminate against any citizen on grounds only of religion, race, caste, sex, place of birth or any of them" (Basu, 2007: 92).

Linguistic discrimination remains more vulnerable in the states of north-east India and few union territories where territorial federalism has stumbled on the question of language. Four northeastern states have overwhelmingly non-scheduled linguistic population comprising several linguistic groups. This has caused the dominance of scheduled languages, minority in totality, in economic and political (public) sphere. The dual underrepresentation in the federal scene compels to look beyond territory.

\section{Consociational Representation: Territory, Identity and Beyond}

The underrepresentation of linguistic minorities can be attributed to the limitation of linguistic territorialism. The bifurcation of Andhra Pradesh into Andhra and Telangana in 2014; creation of Jharkhand, Chhattisgarh and Uttarakhand in 2000 seeks to intensify the need to look beyond territorialism. Though linguistic exclusivity was replaced by the SRC recommendations and subsequent act of 1956, liguism has been implicitly pronounced within popular demand. The developments of 2000 were not the outcome of linguistic questions, evident with their unchanged linguistic majority. India's popular identity is multilayered and often overlaps with each other, sometimes they clash! Demands of new states are not the fruit of only linguistic grievances, other forms of identity also take part in the federal game. Territorial mechanism has not been able to facilitate a durable solution with some or the other forms of identity issues in India's great federal conundrum. Avenues of comparative federalism may provide the opportunity to go for trial and error method with extra-territorial or non-territorial alternative as Indian federation, by large, is deficient in non-territorial power-sharing.

Consociational representation provides for a dual representation i.e. non-territorial representation along with territorial one. Belgium has been an example in mitigating the differences among linguistic groups. It has three linguistic groups and three regions, although not completely identical with each other. Flanders (north) is predominantly Dutch speaking, Wallonia (south) is predominantly resided by Francophone with Germanophone residing in its north-eastern side (Jacobs and Swyngedouw, 2008). Capital Brussels remains somewhat a linguistically heterogeneous region. It has adopted a non-territorial measure in order to do away with the linguistic divide. But as far as multilingualism is concerned, India seems much more heterogeneous. In addition to that, her multilayered and often overlapping identity remains problematic. Non-territorial representation, pardon autonomy in the western sense, will have to face the Indian challenge to ensure integration and prevent segregation. This will not be an easy parallel task to perform. If linguistic territorialism is to be taken into serious consideration, it would be a gigantic and somewhat impossible task for the government leading to disastrous consequences. Linguistic scrutiny based on census report of 2011, India has approximately 1369 languages (Reddy, 2019: 1). More states mean installation of more governmental machinery only to incur huge expenditure. Non-territoriality is waiting to be cultivated in the research of federal policy making. 
7 | Federalism at the Crossroads: Crisis of the Linguistic Minorities in India

\section{Findings}

The paper has got following research findings-

1. Indian federation is mostly the fruit of linguistic territorialism.

2. Linguistic territorialism has been reduced to linguistic majoritarianism and failed to produce sustainable solutions to linguistic minorities.

3. Therefore new minority emerged (it may take the form of non-scheduled linguistic deprivation sometimes) with new demands of separate states.

4. Indian federation has been deficient in non-territorial power-sharing.

5. India's dispersed diversity is looking for a sustainable answer.

6. India's multilayered and often overlapping identity poses an impediment in the way of accommodation of diversity.

\section{Conclusion}

Quite surprisingly, Indian federal exercise has been sustaining despite the demands of states reorganization at frequent intervals. India's federal history shows all initiatives, be it constitutional, extra-constitutional or non-constitutional have implicitly carried forwarded a rigid legacy of linguistic dominance with a belated realization of the ground reality of India's dispersed diversities. This dispersed diversity is looking for another door to knock by challenging the territorial mechanism of accommodation.

\section{References}

All India Congress Committee. (1905). Report of the Benaras Session of the Indian National Congress. 62-69 https://ndl.iitkgp.ac.in

All India Congress Committee. (1920). Report of the Nagpur Session of the Indian National Congress. 10-49 https://ndl.iitkgp.ac.in

All India Congress Committee. (1948). Report of the Linguistic Provinces Commission. 25-35 https://ndl.iitkgp.ac.in

All India Congress Committee. (1949). Report of the Linguistic Provinces Committee. 1-16 https://ndl.iitkgp.ac.in

All India Congress Committee. (2019). Congress Will Deliver. Election Manifesto 2019. 43. https://manifesto.inc.in

Basu, D.D. (2007). Introduction to the Constitution of India. New Delhi: Wadhwa and Company. 91-93

Coakley, J. (2015). Introduction: Dispersed Minorities and Non-Territorial Autonomy. Ethnopolitics, 15(2), 123. https://doi.org/10.1080/17449057.2015.1101842

Groups demand second states reorganization commission. (11 August, 2015). New Delhi. 1-2 https://economictimes.indiatimes.com/news/politics-and-nation/groups-demand

https://eacea.ec.europa.eu/national-policies/eurydice

Jacobs, D., \& Swyngedouw, M. (2001). Territorial and Non-Territorial Federalism in Belgium: Reform of the Brussel's Capital Region. Regional and Federal Studies. 13(2), 127-139.

https://doi.org/10.1080/13597560308559430

Lijphart, A. (1969). Consociational Democracy. World Politics. 21(2), 207-225.

http://www.jstor.org/stable/2009820 
Ministry of Culture to the Government of India. (1955). Reports of the States Reorganisation Commission. 2015-2016. 205-216. https://www.indianculture.gov.in/report-states-reorganisation-commission Ministry of Human Resource Development to the Government of India. (2020). National Education Policy 2020. 51-54. https://www.mhrd.gov.in/sites/upload_files/mhrd/files/NEP_Final_English_o.pdf

Office of the Registrar General, India. (2011). Census of India 2011: Paper 1 of 2018. Language. 13-14. censusindia.gov.in>2011Census $>$ Language_MTs

Pylee, M.V. (2008). India's Constitution. New Delhi: S. Chand. 85-86

Reddy, A. (February 2019). Linguistic Minorities in India: Entrenched legal and educational obstacles to equality. London School of Economics. 1-4 blogs.lse.ac.uk/southasia/2019/02/21/linguistic-minoritiesin-india

Watts, R. (2007). The Federal Idea and its Contemporary Relevenace. Ontario: Institute of Intergovernmental Relations, Queen's University. 3-4

What Congress Stands. (27 October, 1945). Amrita Bazar Patrika. Calcutta. 1. https://ndl.iitkgp.ac.in

The author is an Assistant Professor and Head, department of Political Science at Government General Degree College, Tehatta from Nadia, West Bengal, India. Besides, he is pursuing Ph.D in Political Science at the University of Burdwan, West Bengal, India. He is a life member of the West Bengal Political Science Association. Paper presented in fifteen national/international conferences including the RIOC. He has three publications including two seminar proceedings. He had the privilege to be invited to judge a competition on 'Corporate Social Responsibility' in the St. Xavier's College, Park Street, Kolkata, India in 2017. 